Yüzüncü Yil Üniversitesi
Tarim Bilimleri Dergisi

Araştırma Makalesi (Research Article)

\title{
Van İli İpekyolu İlçesinde Üretilen Yonca Kuru Otunun Hasattan Depolamaya Kadar Besin Madde Kompozisyon Düzeyindeki Değişimin İncelenmesi**
}

\author{
Emine AÇIKGÖZ*1, Murat DEMIREL ${ }^{2}$ \\ ${ }^{1}$ İpekyolu Tarım ve Orman İlçe Müdürlüğü 65130, Van, Türkiye \\ ${ }^{2}$ Yüzüncü Yıl Üniversitesi, Ziraat Fakültesi, Zootekni Bölümü, 65080, Van, Türkiye \\ ${ }^{1}$ https://orcid.org/0000-0002-9913-0352 ${ }^{2}$ https://orcid.org/0000-0002-2992-8393 \\ *Sorumlu yazar e posta: zm.emineacikgoz@hotmail.com
}

Makale Bilgileri
Geliş: 30.11 .2020
Kabul: 20.01 .2021
Online Yayınlanma 30.03.2021
DOI: 10.29133 yyutbd.833824

Anahtar kelimeler

Aflatoksin,

Besin maddesi,

Yonca kuru otu.
Öz: Bu çalışmada, Van ili İpekyolu ilçesine bağlı farklı köylerde üretimi yapılan yoncanın hasattan depolanıncaya kadar geçen süreçteki besin madde değişimleri incelenmiş̧tir. Araştırma alanı olarak 208 işletme içerisinden tabakalı tesadüfî örnekleme yöntemi ile 30 işletme belirlenmiştir. Karagündüz köyünde hasat edilen yoncaların ortalama kuru madde miktarı \% 40.90 olup Ağzıkara köyü hariç diğer köylere göre yüksek bulunmuştur $(\mathrm{P}<0.05)$. Hasat sonrası kapalı ortamda kurutulan yoncaların ortalama ham protein (HP) içeriği \% 15.30 iken, bu değer tarlada kurutma sonrasında \% 12.67'ye, depolamada ise \% 11.82'ye düşmüştür $(\mathrm{P}<0.05)$. Hasat sonrası kapalı ortamda kurutulan yoncaların ortalama \% 9.89 olan Asit Deterjan Lignin (ADL) içerikleri, depolamada \% 11.61'e yükselmiştir $(\mathrm{P}<0.05)$. Hasat sonrası kapalı ortamda kurutulan yoncaların ortalama \% 140.86 olan toplam karoten ve \% 1.66 olan kalsiyum içerikleri tarlada kurutma ve depolamada düşmüştür $(\mathrm{P}<0.05)$. Hasatta, tarlada kurutmadan sonra ve depolama sürecinde alınan yonca kuru otu örneklerinde Aflatoksin B1, B2, G1 ve G2' ye rastlanılmamıştır. Sonuç olarak, hasatla birlikte yoncanın HP, Ca ve toplam karoten düzeylerinde bir miktar kayıplar görülmekle birlikte, yemlerde aflatoksin düzeyine rastlanılmaması yem kalitesi açısından önemli bir sonuç olarak görülmektedir.

\section{Investigation of the Change in Nutrient Composition Level of Alfalfa Hay Cultivated in İpekyolu District of Van Province from Harvest to Storage}

\section{Article Info}

Received: 30.11.2020

Accepted: 20.01.2021

Online Published 30.03.2021

DOI: $10.29133 /$ yyutbd.833824

\section{Keywords}

Aflatoxin,

Alfalfa hay,

Nutrient matters.

\begin{abstract}
In this study, the nutrient changes of the alfalfa hay from harvesting to storage period produced in different villages of the İpekyolu District of Van was examined. 208 enterprises cultivated alfalfa was determined as the research areas and 30 enterprises were selected by stratified random sampling method. The average dry matter content of alfalfa hay harvested in Karagündüz village was $40.90 \%$ and was higher than other villages except Ağzıkara village $(\mathrm{P}<0.05)$. While the average crude protein (HP) content of alfalfa hay dried in a closed environment after harvest was $15.30 \%$, this value decreased to $12.67 \%$ after drying in the field and to $11.82 \%$ in storage $(\mathrm{P}<0.05)$. While the average Acid Detergent Lignin (ADL) contents were $9.89 \%$ at the time of alfalfa hay dried in a closed environment, this rate increased to $11.61 \%$ during storage $(\mathrm{P}<0.05)$. Although the total carotene content and calcium content at the time of alfalfa hay dried in a closed environment were $140.86 \%$ and $1.66 \%$ respectively, this level decreased after drying in the field and after storage $(\mathrm{P}<0.05)$. Aflatoxin B1, B2, G1 and G2 were not found in alfalfa hay samples during harvesting, drying and storage periods times. As a result, although some losses were observed in $\mathrm{HP}, \mathrm{Ca}$ and total carotene levels of alfalfa with the harvest, not finding aflatoxin levels in
\end{abstract}


feeds is seen as an important result in terms of feed quality.

**Bu çalışma FYL-2018-7198 numaralı Yüksek Lisans Tez Projesinden üretilmiștir.

\section{Giriş}

Kaba yemlerin besin madde veya fiziksel yapı bakımından en doğal halleri biçilmeden veya otlatılmadan hemen önceki halleri olup zamana bağlı olarak doğal yapısından uzaklaşmaktadır. Hasat sonrası kimi zaman fiziksel kimi zaman da kimyasal yapısının değişimi ile istisnai durumlar hariç, yem kalitesi düşmektedir.

Yemlerin, hasat anından hayvanın yemliğine gelinceye kadar ki tüm aşamalarda çeşitli besin madde kayıpları olabileceği gibi değişik mikroorganizmalarla bulaşmaları neticesinde de kalite kayıpları söz konusu olabilmektedir (Basmacıŏlu ve Ergül, 2003). Yonca kuru otunun besin madde düzeyi biçim zamanından etkilenmekteyken (Fan ve ark., 2018; Stavarache ve ark., 2015) hasat sonrasında da kurutma, taşıma ve depolama gibi faktörler de besin madde miktarının azalmasına neden olmaktadır (Nascimento ve ark., 2000; Neres ve ark., 2010). Hasat döneminde yemlere uygulanan fiziki işlemlerin yanında tarlada yemlerin bekletilme süreleri ile yağışa ve güneșe maruz bırakılma süreleri ve toprakla temas süreleri besin madde kayıplarının yanında, rutubet ve sıcaklığa bağlı olarak mantar türleri hızla üreyerek mikotoksin (küf) oluşturmaktadır (Arıkan ve Çevik, 2012). Açıkta depolanan kaba yemlerin yağan kar, yağış ve çiğ etkisiyle küf mantarları için uygun ortam oluşturduğu, mantarların faaliyetleri sonucu yemlerde çürüme ve kızışma ile oluşan KM ve HP ile sindirilebilir protein kayıplarının önlenmesinin mümkün olduğu bildirilmektedir (Bastaban ve ark., 1983).

Van ili yetiştirici şartlarında elde edilen ve depolanan kaba yem örneklerinin nem içerikleri ile yıllık yağış, sıcaklık ve nispi nem ortalamaları bakımından yemlerde aflatoksin oluşumu ile toksijenik küf gelişimi bakımından olumsuz etkilenmemekle birlikte yağmur sularının yem yı̆̆ınlarına sızmasından kaynaklanan lokal aflatoksin oluşumu hasatta yemlerin iyice kurutulması, mikroorganizma kontaminasyon şartlarının giderilmesi ve yemlerin yağış almayacak şekilde depolanması ile büyük ölçüde önlenebileceği bildirilmektedir (Demirel ve Yıldırım, 2001).

Yem kalitesinin bitki türü, hasat zamanındaki olgunluk durumu, kurutma ve saklama metotları ile değiştiği düşünüldüğünde; yonca üretimi yapan çiftçilerin üretmiş oldukları yoncanın hasat anından hayvanın yemliğine gelinceye kadar ki süreçte olası besin madde değişimlerinin durum tespitinin yapılması ve var olan besin maddelerinin minimum kayıpla muhafazası ve doğru uygulamaların önerilmesi çalışmanın amacını oluşturmaktadır.

\section{Materyal ve Yöntem}

Van il genelinde 2014-2018 yılları arasında desteklenen yem bitkilerinin alanları, 26638 dekar yonca ve 7760 dekar korungadan oluşmuş iken, Van ili İpekyolu ilçesi sınırları içerisinde bu alanların 7859 dekar yonca ve 3641 dekarlık kısmının korunga olduğu bildirilmektedir (Anonim, 2018). Bu bağlamda çalışmanın materyalini, Van ili İpekyolu ilçesi Tarım ve Orman İlçe Müdürlüğü Yem Bitkisi ve Hayvan Sağlığı Birimi verilerine dayanarak Van ili İpekyolu ilçesine bağlı 8 köyde (Ağzıkara, Gövelek, Karagündüz, Karakoç, Ortanca, Yalınağaç, Yukarıüneyce ve Erçek) yonca üretimi yapan 208 işletmeciyi temsil edecek şekilde 30 işletmecinin ürettiği yonca otu örnekleri oluşturmuştur.

İşletmelerde yonca üretimi amaciyla genelde Kayseri ve Bilensoy yerli yonca tohumu çeşitlerinin kullanıldığı ifade edilmiş ve bu durum yapılan bir çalışmada da teyit edilmiş̧tir (Turan, 2010). Örneklemede kullanılan yonca tarlaların tamamı tesis (ekim) yılından sonraki üretim yılında değerlendirmeye alınmış olup üreticilerle yapılan görüşmelerde yonca tarlalarına sadece ekim döneminden önceki sonbaharda hayvansal gübre uygulandığ ifade edilmiştir.

Denemenin yürütüldüğü 2018 y1lına ait meteorolojik veriler Çizelge 2.1'de görülmektedir (Anonim, 2019). 
Çizelge 2.1. Denemenin yürütüldüğü yıla ait dört farklı istasyona ait iklim verileri

\begin{tabular}{|c|c|c|c|c|c|c|c|c|}
\hline \multicolumn{9}{|c|}{ Aylar } \\
\hline Veriler & İstasyon & May1s & Haziran & Temmuz & Ağustos & Eylül & Ekim & Kasım \\
\hline \multirow{4}{*}{$\begin{array}{c}\text { Ortalama } \\
\text { Sicaklık } \\
\left({ }^{\circ} \mathrm{C}\right)\end{array}$} & $1 *$ & 17.50 & 24.06 & 31.38 & 29.23 & 25.54 & 17.24 & 8.16 \\
\hline & $2 *$ & 14.66 & 20.66 & 27.76 & 26.52 & 21.35 & 13.26 & 5.28 \\
\hline & $3 *$ & 14.73 & 21.00 & 28.12 & 26.89 & 22.55 & 14.87 & 5.99 \\
\hline & $4 *$ & 19.54 & 25.23 & 31.09 & 30.03 & 26.29 & 19.18 & 11.24 \\
\hline \multirow{4}{*}{$\begin{array}{c}\text { Toplam } \\
\text { Yağış (mm) }\end{array}$} & $1 *$ & 4.03 & 0.67 & 0.23 & 0.10 & 0.02 & 1.75 & 0.98 \\
\hline & $2 *$ & 3.84 & 0.53 & 0.01 & 0.08 & 0.03 & 2.45 & 1.77 \\
\hline & $3 *$ & 3.81 & 1.35 & 0.33 & 0.00 & 0.04 & 2.33 & 0.96 \\
\hline & $4 *$ & 3.85 & 0.53 & 0.01 & 0.08 & 0.03 & 2.45 & 1.77 \\
\hline \multirow{4}{*}{$\begin{array}{c}\text { Oransal } \\
\text { Nem (\%) }\end{array}$} & $1^{*}$ & 64.48 & 49.62 & 31.97 & 38.70 & 40.13 & 64.54 & 79.36 \\
\hline & $2 *$ & 82.72 & 61.10 & 32.08 & 37.67 & 30.04 & 66.96 & 90.40 \\
\hline & $3 *$ & 80.13 & 56.68 & 31.34 & 37.86 & 37.45 & 62.99 & 87.72 \\
\hline & $4 *$ & 58.65 & 45.57 & 30.51 & 41.96 & 40.11 & 59.60 & 72.40 \\
\hline $\begin{array}{l}\text { Güneşlenme } \\
\text { süresi (Saat) }\end{array}$ & & 7.87 & 11.43 & 12.02 & 11.51 & 10.05 & 6.81 & 4.34 \\
\hline
\end{tabular}

2018 yılına ait (1* Özalp, 2* Ortanca, 3* Yukarıüneyce, 4* Van Merkez Meteoroloji istasyonları).

Örnek hacminin belirlenmesinde tabakalı tesadüfi örnekleme yöntemi kullanılmış ve ana kitleyi temsil edebilecek örnek hacmi Ağzıkara köyünde 5, Gövelek köyünde 4, Karagündüz köyünde 5, Karakoç köyünde 5, Ortanca köyünde 3, Yalınağaç köyünde 2, Yukarıüneyce köyünde 3 ve Erçek köyünde 3 işletme olmak üzere toplam 30 işletme belirlenmiştir (Erkan ve ark., 1991).

$$
n=\frac{N \sum N h S^{2} h}{N^{2} D^{2}+\sum N h S^{2} h}
$$

Formülde $\mathrm{n}$ örnek hacmini, $\mathrm{N}$ ana kitledeki işletme sayısını, $\mathrm{Nh}$ h' 1ncı tabakadaki işletme sayısını, $S^{2} h$ h' 1ncı tabakadaki varyansı göstermektedir. $D^{2}=d^{2} / Z^{2}$ dir. Burada d kitle ortalamasında müsaade edilen hata miktarını ve $Z$ ise belirlenen hata oranına göre, standart normal dağılım tablosundaki $\mathrm{Z}$ değerini belirtmektedir. Örnek hacminin belirlenmesinde $\% 10$ hata payı ve \% 90 güvenirlik sınırları içinde çalışılmışıtır.

İşletmeler sahip oldukları yonca ekim alanlarına göre üç gruba ayrılmıştır. 16 dekardan az yonca ekim alanına sahip olan 10 işletme I. grubu, 16-30 dekara sahip olan 14 işletme II. grubu ve 30 dekardan fazla yonca ekim alanına sahip 6 işletme ise III. grubu oluşturmuştur. Deneme yapılacak olan işletmeler araştırma alanındaki işletmelere oransal dağılım esasına dayanarak paylaştırılmıştır. Yem örnekleri hasat anında (haziran-temmuz ayları), tarlada kuruduktan sonra (temmuz-ağustos ayları) ve depoda (kasım ayı) olacak şekilde üç farklı dönemde alınmıştır. Hasat zamanı yeşil yonca otları, hasat sonrası namlular ve bağ halinde tarlada kurtulan kuru yonca otları ve depo genelini kapsayacak şekilde her bir çiftçinin kendi koşullarında depoladığı yonca kuru otlarından (usulüne uygun örnekleme ile numune alınmıştır (Kutlu, 2008 ).

Deneme materyalini oluşturan ilgili her bir köydeki çiftçilerin yonca üretimleri ile ilgili işlemlerine ait tanıtıcı bilgiler özet olarak verilmiştir.

Ağzıkara köyünde yetiştiricilerin 4'ünün kuru yonca tarımı 1'inin ise sulu yonca tarımı yaptığ1 ve sulu tarım yapan yetiştiricinin çiçeklenme ortasında tırpanla, kuru tarım yapanların ise çiçeklenme sonunda makine ile hasat ettikleri görülmüştür. Tüm yetiştiriciler yonca otlarının hasattan sonra tarlada bağ şeklinde 15 gün kurutup römorkla depolama alanlarına taşımışlardır. Taşınan otlar ahırların üzerinde veya ahır yakınındaki boşluklarda yığın (taya) şeklinde 4 ay üstü açık olarak beklettikleri ve kasım ayı sonuna doğru otların üzerini çadırla örttükleri gözlemlenmiştir.

Erçek köyünde yetiştiricilerin 2'sinin kuru yonca tarımı 1'inin ise sulu yonca tarımı yaptığı ve sulu tarım yapan yetiştiricinin yoncayı çiçeklenme başında makineyle, kuru tarım yapanların ise tam çiçeklenme döneminde makine ile hasat ettikleri görülmüştür. Kuru tarım yapan yetiştiriciler yonca otlarını hasattan sonra tarlada bağ şeklinde 10 gün, sulu tarım yapan ise namlu halinde 4-5 gün kurutup römorkla depolama alanlarına taşımışlardır. Kuru tarım yapan yetiştiriciler taşınan otları ahırların üzerinde veya ahır yakınınki boşluklarda yığın (taya) şeklinde 4 ay üstü açık bekletip kasım 
ayı sonuna doğru üzerlerini çadırla örterken sulu tarım yapanın ise patozlayıp kes haline getirdiği yonca otunu kerpiç duvarlarla çevrili kapalı bir ortamda depoladığı gözlemlenmiştir.

Gövelek köyündeki yetiştiriciler, köylerinin diğer köylere göre fazla yağış aldığını düşünerek kuru yonca tarımı yaptıkları, yoncaları çiçeklenme başlangıcında biçme makinası ile hasat edip yonca otlarını tarlada bağ şeklinde 7 gün kuruttuktan sonra römorkla taşıdıkları görülmüştür. Yetiştiricilerin 1'inin taşınan otları evin bahçesinde yığın (taya) şeklinde 4 ay üstü açık bekletip kasım ayı sonuna doğru üzerini çadırla örterken 3'ünün ise patozlayıp kes haline getirdikleri yonca otunu kerpiç duvarlarla çevrili kapalı bir ortamda depoladıkları gözlemlenmiştir.

Karagündüz köyündeki yonca üretimi yapan işletmelerin 2 tanesi kuru 1 tanesi sulu tarım yapmıştır. 2 işletme ise kuru tarım yapmakla birlikte, tarlalarının Erçek Gölü kenarında ve taban suyunun yüksek olması nedeniyle sulu tarım özelliği göstermektedir. Yetiştiricilerin 2'sinin tohum bağlama başlangıcında, 3'ünün ise çiçeklenme sonunda makine ile hasat ettiği görülmüştür. Yetiştiriciler yoncalarını hasattan sonra tarlada bağ şeklinde 10-15 gün tarlada kurutup römorkla depolama alanlarına taşımışlardır. Yetiştiricilerin 3'ünün taşınan otları ahırların üzerinde veya ahır yakınınki boşluklarda yığın (taya) şeklinde 4 ay üstü açık bekletip kasım ayı sonuna doğru üzerini çadırla örterken 2'isinin ise patozlayıp kes haline getirdikleri yonca otunu kerpiç duvarlarla çevrili kapalı bir ortamda depoladıkları gözlemlenmiştir.

Karakoç köyündeki yetiştiriciler, köylerinin diğer köylere göre fazla yağış aldığını düşünerek kuru yonca tarımı yaptıkları, yoncaları çiçeklenme başlangıcında makina ile hasat ettikleri, 2 yetiştiricinin hasat edilen otları tarlada bağ şeklinde 15 gün ve 3 yetiştiricinin ise namlu halinde 5-6 gün kurutup römorkla taşıdıkları görülmüştür. Yetiştiricilerin 2'sinin taşınan otları evin bahçesinde yığın (taya) şeklinde 4 ay üstü açık bekletip kasım ayı sonuna doğru üzerini çadırla örterken 3’ünün ise patozlayıp kes haline getirdikleri yonca otunu kerpiç duvarlarla çevrili kapalı bir ortamda depoladıkları gözlemlenmiştir.

Ortanca köyündeki yetiştiricilerin de aynı şekilde köylerinin diğer köylere göre fazla yağış aldığını düşünerek kuru yonca tarımı yaptığı, yetiştiricilerin 2'sinin yoncayı çiçeklenme başlangıcında, 1'inin ise çiçeklenme ortasında makine ile hasat ettikleri görülmüştür. 1 yetiştiricinin hasat edilen otları tarlada bağ şeklinde 15 gün ve 2 yetiştiricinin ise namlu halinde 7 gün kurutup römorkla taşıdıkları görülmüştür. Yetiştiricilerin 1'inin taşınan otları evin bahçesinde yığın (taya) şeklinde 4 ay üstü açık bekletip kasım ayı sonuna doğru üzerini çadırla örterken 2'sinin ise patozlayıp kes haline getirdikleri yonca otunu kerpiç duvarlarla çevrili kapalı bir ortamda depoladıkları gözlemlenmiştir.

Yalınağaç köyündeki 2 yetiştiricinin de kuru yonca tarımı yaptıkları, çiçeklenme ortasında makine ile hasat ettikleri otlarını tarlada bağ şeklinde 15 ve 25 gün kurutup römorkla taşıdıkları görülmüştür. İki işletmenin de patozlayıp kes haline getirdikleri yonca otunu işletme yanında açıkta 50-60 gün üstü açık bekletip sonra çadırla üzerlerini örttükleri gözlemlenmiştir.

Yukarıüneyce köyündeki 3 yetiştiricinin ise sulu yonca tarımı yaptıkları, çiçeklenme başlangıcında makine ile hasat ettikleri otlarını namlu halinde 5 gün tarlada kurutup römorkla taşıdıkları görülmüştür. Üç işletmeninde patozlayıp kes haline getirdikleri yonca otunu kerpiç duvarlarla çevrili kapalı bir ortamda depoladıkları gözlemlenmiştir.

Hasat zamanı örneklemesi havanın güneşli olduğu günlerde sabah saatlerinde yapılmıştır. Yonca otu örneklemesi, bitki florası homojen olan yonca tarlalarında 1'er $\mathrm{m}^{2}$ 'lik 13 adet farklı alanda 5 'er kg örnek alınarak karıştırılmış ve bu karışımda $10 \mathrm{~kg}$ yaş yem örneği alınarak yapılmıştır. Biçim anındaki KM ölçümü için alınan örnekler hızlı bir şekilde laboratuvara getirilmiştir. Örnek oda sıcaklığında, serin rutubetsiz ve kapalı ortamda kurutulmuştur. Hasattan sonra bağ, bağ yığını veya namlu halinde tarlada kurutmaya bırakılan (tarlada kurutma) yonca kuru otundan havanın açı ve güneşli olduğu günlerde yonca otlarının genelini temsil edecek şekilde 13 farklı noktadan kuruyan otun yapısına zarar vermeyecek şekilde alınan yonca otu örnekleri karışımından yaklaşık $2 \mathrm{~kg}$ yonca otu örneklemesi yapılmıştır. Bir sonraki örnek alma işlemi olan depo dönemi ise yağışlı günlerde olmuştur. Yonca otlarının depolandığı açık ve kapalı alanlardaki ot yığınlarından ve kes haline getirilerek kapalı ortamlarda depolanan yonca otundan bütünü temsil edecek (depolama sonrası) örnekler alınmıştır. Ana kitleyi temsilen 30 işletmeye ait üç farklı zamanda (hasat anında alınan fakat kapalı ortamda kurutulmuş, tarlada kurutma sonrası ve depolama sonrası) alınıp poşetlenen yonca otu örnekleri $1 \mathrm{~mm}$ 'lik elekten geçebilecek şekilde değirmende öğütülmüş ve 500 g'lık kısmı alınıp analizlerin yapılacağı zamana kadar derin dondurucuda saklanmıştır. 
Yem örneklerinde KM, HP ve HK içerikleri (AOAC, 1990) göre, ADF, NDF ve ADL analizleri (Van Soest ve ark., 1991) ve Ham Yağ analizi Ankom XT15 cihazı kullanılarak (Komarek, ve ark., 2004) yapılmıştır. Toplam karoten analizleri (Stancher ve Zonta, 1982), aflatoksin analizi numuneden toksin ekstrakte edilme prensibine (AOAC, 2005) göre HPLC cihazında okutulmuştur. Ca, K, Na ve Mg analizleri (Karabulut ve Canbolat, 2005) yöntemine göre Atomik Absorbsiyon cihazında okutulmuştur. Denemede elde edilen veriler (SAS, 2014) paket programı kullanılarak General Linear Model (PROC GLM) prosedürü ile varyans analizine tabi tutulmuştur. Gruplara ait ortalamaların karşılaştırılmasında DUNCAN çoklu karşılaştırma testi kullanılmıştır. Veriler aşağıdaki matematik modele göre analiz edilmiştir.

$\mathrm{y}_{\mathrm{u}}=\mu+\mathrm{a}_{\mathrm{i}}+b \mathrm{j}+e_{i j}$

$y_{i j}$ : i’ nci örnek alma dönemi ve j’ nci köyden elde edilen cevap değişkeni (burada cevap değişkenlerini; KM, HP, HK, HY, ADF, NDF, ADL, Topam karoten, Ca, K, Na ve Mg göstermektedir)

$a_{i}$ : i’ nci örnek alma döneminin etki payı

$b_{j}:$ j' nci köyün etki pay1

$e_{i j}$ : Şansa bağlı hata payı

\section{Bulgular ve Tartışma}

Van ili İpekyolu ilçesinin farklı köylerinde hasat edilen yoncanın KM değerleri arasında farkl11ıkların olduğu ve özellikle Karagündüz köyünde biçilen yoncaların KM'si \% 40.90 olup Ağzıkara köyü hariç diğer köylere göre önemli derecede yüksek bulunmuştur $(\mathrm{P}<0.05)$. Ağzıkara köyünde biçilen yoncaların hasat anındaki KM düzeyi ise \% 37.50 ile Yukarıüneyce köyünde üretimi yapılan yonca $(\%$ 28.48) KM'sine göre yüksek iken $(\mathrm{P}<0.05)$, diğer köylerle benzer bulunmuştur (Çizelge 3.1). Karagündüz köyünde yonca hasadı çiçeklenme sonu tohum bağlama başlangıcında yapıldığı, Ağzıkara köyünde daha çok çiçeklenme sonunda diğer köylerde ise çiçeklenme başlangıcı veya çiçeklenme ortalarında yapıldığı tespit edilmiştir. Erken çiçeklenme döneminde hasat edilen yonca KM’sinin \% 28.07'den çiçeklenme sonunda \% 41.07'e ulaştığ (Dumlu Gül ve ark., 2015), erken çiçeklenme döneminde düşük olan KM'nin vejetatif dönemin ilerlemesi ile yükseldiği ve tohum bağlama döneminde en yüksek düzeye ulaştığı bildirilmektedir (Kim ve ark., 2004; Ünalp, 2014; Adiyaman ve Ayhan, 2016).

Kapalı ortamda kurutma, tarlada kurutma ve depolanma sonras1 yonca otunun KM düzeylerinin genel ortalamalarının farklılık gösterdiği, tarlada kurutulmuş yoncada \% 94.13 olan KM değerinin depolamada \% 91.67’ye düştüğü görülmüştür ( $\mathrm{P}<0.05$; Çizelge 3.1). Ağzıkara, Karagündüz, Ortanca, Yalınağaç ve Yukarıüneyce köylerinde depolardan alınan örneklerin \% KM değerleri sirasıyla \% 92.03, 89.85, 92.39, 90.06 ve \% 89.82 olduğu, tarladan alınan örneklere göre düştüğü $(\mathrm{P}<0.05)$ görülmüştür. Ortanca köyünde tarlada kurutulmuş yonca otunun \% KM'si \% 96.50 ile diğer köylerden yüksek iken depolardan alınan yonca örneklerinin \% KM'si Erçek ( \% 93.53) ve Yukarıgüneyce $(\%$ 89.82) köyleri birbirinden farklı $(\mathrm{P}<0.05)$ olmakla birlikte diğer köyler benzer bulunmuştur. Hasat edilen yonca otları tarlada namlu veya bağ şeklinde her bir köyde farklı sürelerde bekletilmiştir. Tarlada güneşte uzun süre bekletilmesi yemlerin KM içeriğini artırabileceği gibi tarlada veya depoda otların yağmura maruz kalması KM içeriğinin düşmesini kaçınılmaz kılacaktır. Nitekim hasat edilen yoncanın tarlada bekletme süresi her bir köyde değişmekle birlikte ortalama 4-25 gün olduğu tespit edilmiştir. Kuru maddede görülen değişime hasat sonrası tarlada bekletilme süresinin etkili olabileceği gibi yemlerin depoya taşınmasındaki kayıpların yanında iklim koşullarının da etkili olduğu bildirilmektedir (Oktay ve ark., 1984). 
Çizelge 3.1. Yonca otunun hasat anında ve hasat sonrasındaki \% KM değerlerine ait en küçük kareler ortalaması ve standart hata sonuçları

\begin{tabular}{llllll}
\hline \multirow{2}{*}{ Köyler } & $\begin{array}{l}\text { Hasat anında yonca } \\
\text { yeşil otunun \% KM }\end{array}$ & $\mathrm{N}$ & & \multicolumn{3}{l}{ Hasat sonras1 yonca otunun kuru madde (\%) içeriği } \\
\cline { 4 - 6 } & içeriği & $\begin{array}{l}\text { Kapalı ortamda } \\
\text { kurutma }\end{array}$ & Tarlada kurutma & Depolama sonras1 \\
\hline Ağzıkara & $37.50 \pm 2.14^{\mathrm{ab}}$ & 5 & $93.69 \pm 0.30^{\mathrm{Aa}}$ & $93.82 \pm 0.50^{\mathrm{Ab}}$ & $92.03 \pm 0.58^{\mathrm{Bab}}$ \\
Erçek & $32.33 \pm 2.49^{\mathrm{bc}}$ & 3 & $92.42 \pm 0.42^{\mathrm{Bb}}$ & $94.45 \pm 0.16^{\mathrm{Ab}}$ & $93.53 \pm 0.16^{\mathrm{Aa}}$ \\
Gövelek & $31.29 \pm 1.04^{\mathrm{bc}}$ & 4 & $92.42 \pm 0.09^{\mathrm{Bb}}$ & $94.08 \pm 0.31^{\mathrm{Ab}}$ & $93.28 \pm 0.33^{\mathrm{Aab}}$ \\
Karagündüz & $40.90 \pm 2.27^{\mathrm{a}}$ & 5 & $94.06 \pm 0.29^{\mathrm{Aa}}$ & $94.08 \pm 0.25^{\mathrm{Ab}}$ & $89.85 \pm 1.70^{\mathrm{Bb}}$ \\
Karakoç & $29.13 \pm 0.95^{\mathrm{bc}}$ & 5 & $92.28 \pm 0.18^{\mathrm{b}}$ & $93.04 \pm 0.54^{\mathrm{b}}$ & $92.02 \pm 0.95^{\mathrm{ab}}$ \\
Ortanca & $29.24 \pm 1.80^{\mathrm{bc}}$ & 3 & $91.22 \pm 0.73^{\mathrm{Bc}}$ & $96.50 \pm 1.20^{\mathrm{Aa}}$ & $92.39 \pm 0.43^{\mathrm{Bab}}$ \\
Yalınağaç & $32.09 \pm 1.68^{\mathrm{bc}}$ & 2 & $91.02 \pm 0.003^{\mathrm{Bc}}$ & $94.05 \pm 0.10^{\mathrm{Ab}}$ & $90.06 \pm 0.31^{\mathrm{Cab}}$ \\
Yukarigüneyce & $28.48 \pm 0.17^{\mathrm{C}}$ & 3 & $92.66 \pm 0.16^{\mathrm{Ab}}$ & $93.93 \pm 0.70^{\mathrm{Ab}}$ & $89.82 \pm 0.50^{\mathrm{Bb}}$ \\
Genel ortalama & & 30 & $92.69 \pm 0.21^{2}$ & $94.13 \pm 0.29^{1}$ & $91.67 \pm 0.40^{3}$ \\
\hline
\end{tabular}

A,B, C: Aynı satırdaki farklı harfleri taşıyan değerler arasındaki farklılık önemlidir $(\mathrm{P}<0.05)$; a,b,c: Aynı sütundaki farklı harfleri taşıyan değerler arasındaki farklılıklar önemlidir $(\mathrm{P}<0.05)$; 1.2.3: Aynı satırdaki farklı rakamları taşıyan değerler arasında farklılık önemlidir $(\mathrm{P}<0.05)$.

Kapalı ortamda kurutma, tarlada kurutma ve depolanma sonrası yonca otunun HP, HK ve ADL içeriklerinin genel ortalamaları arasındaki farklılık $(\mathrm{P}<0.05)$ önemli bulunmuştur. Özellikle kapalı ortamda kurutulmuş yoncanın HP içeriği köyler genel ortalaması \% 15.30’lardan tarlada kurutulmuş yoncada \% 12.67'ye ve depolardan alınan yem örneklerinde ise bu değer \% 11.82'ye düşmüştür $(\mathrm{P}<0.05)$. Kapalı ortamda ve tarlada kurutulan yoncanın HK düzeyleri benzer iken depodan alınan örneklerde bu değerin \% 10.87'ye yükseldiği $(\mathrm{P}<0.05)$, benzer şekilde hasat sonrası kapalı ortam ve tarlada kurutulan yoncanın ADL düzeyleri benzer iken depodan alınan örneklerde ise bu değerin, \% 11.61'e yükseldiği görülmüştür $(\mathrm{P}<0.05$; Çizelge 3.2$)$. Hasat sonrası zamana bağlı olarak yonca otu HP oranının düşmesi, HK ile ADL oranlarının yükselmesi taşıma ve depolama yapılırken yonca otunun maruz kaldığı doğal veya fiziksel işlemlerden kaynaklanmaktadır. Hatta tarladan depolamaya kadar ki süreçte kuru ot örneklerine taş, toprak, kum ve çakıl gibi inorganik maddelerin bulaşmış olabileceği ihtimalini artırmaktadır.

Karagündüz, Karakoç, Ortanca ve Yalınağaç köylerinde hasat sonrası kapalı ortamda kurutulan yoncanın sirasiyla \% 15.06, 16.56, 17.35 ve 14.12 olan \% HP miktarı tarlada kurutmada olduğu gibi depolamada \% 10.74, 13.66, 10.37 ve 9.03 düzeylerine düşmüştür $(\mathrm{P}<0.05)$. Ağzıkara, Ortanca ve Yukarıgüneyce köylerinde hasat sonrası kapalı ortamda ve tarlada kurutmada düşük olan yonca \% HK miktarı depodan alınan örneklerde sırasıyla \% 11.21, 11.65 ve \% 11.54'e yükselmiştir $(\mathrm{P}<0.05)$. Erçek köyünde hasat sonrası kapalı ortamda kurutulan yoncanın \% 7.99 olan ADL düzeyi tarladan alınan örneklerde \% 10.38'e ve depodan alınan örneklerde ise \% 12.28'e yükselmiştir $(\mathrm{P}<0.05)$. Ağzıkara ve Karagündüz köylerinde hasat sonrası kapalı ortamda kurutulan yoncada yüksek olan \% HY miktarı tarlada kurutma sonrası bir miktar düşmüştür $(\mathrm{P}<0.05)$. Karakoç köyünde hasat sonrası kapalı ortamda kurutulan yoncada yüksek (\% 71.15) olan NDF miktarı tarlada kurutma ve depolamada sonrası alınan örneklerde düşerken düşük olan ADF miktarı ise depodan alınan yoncada \% 37.59'a yükselmiştir $(\mathrm{P}<0.05)$. HY, ADF ve NDF bakımından diğer köylerde örnek alma dönemleri arasında farklılık gözlenmemiştir.

Hasat sonrası kapalı ortamda kurutulan yoncanın HP oranları köyler arasında farklılık bulunmazken, tarlada kurutulmuş ve depodan alınan örneklerde farklılık bulunmuştur $(\mathrm{P}<0.05)$. 
Çizelge 3. 2. Yonca kuru otlarının kimi besin madde değerlerine ait en küçük kareler ortalaması ve standart hata sonuçları (\% km'de)

\begin{tabular}{|c|c|c|c|c|c|c|c|}
\hline \multirow[t]{2}{*}{ Köyler } & \multirow[t]{2}{*}{$\mathrm{N}$} & \multicolumn{3}{|l|}{$\% \mathrm{HP}$} & \multicolumn{3}{|l|}{$\% \mathrm{HY}$} \\
\hline & & $\begin{array}{l}\text { Kapalı } \\
\text { kurutma }\end{array}$ & Tarlada kurutma & Depolama sonrasi & $\begin{array}{l}\text { Kapalı } \\
\text { kurutma }\end{array}$ & Tarlada kurutma & Depolama sonras \\
\hline Ağgıkara & 5 & $14.29 \pm 0.62$ & $13.30 \pm 0.72^{\mathrm{a}}$ & $12.09 \pm 0.70^{\mathrm{abc}}$ & $9.00 \pm 0.19^{\mathrm{Aa}}$ & $6.87 \pm 0.48^{\text {Babc }}$ & $9.20 \pm 0.20^{\mathrm{Aa}}$ \\
\hline Erçek & 3 & $13.76 \pm 1.04$ & $12.32 \pm 0.70^{\mathrm{a}}$ & $12.05 \pm 1.70^{\mathrm{abc}}$ & $8.57 \pm 0.18^{\mathrm{ab}}$ & $6.54 \pm 0.30^{\mathrm{bc}}$ & $7.53 \pm 1.12^{\mathrm{ab}}$ \\
\hline Gövelek & 4 & $14.39 \pm 1.35$ & $13.09 \pm 1.54^{\mathrm{a}}$ & $11.17 \pm 0.50^{\mathrm{abc}}$ & $8.36 \pm 0.30^{\mathrm{ab}}$ & $7.12 \pm 0.41^{\mathrm{ab}}$ & $7.06 \pm 1.25^{a b}$ \\
\hline Karagündüz & 5 & $15.06 \pm 0.95^{\mathrm{A}}$ & $12.82 \pm 0.74^{\mathrm{ABa}}$ & $10.74 \pm 0.98^{\mathrm{Babc}}$ & $7.54 \pm 0.31^{\text {Aab }}$ & $5.37 \pm 0.16^{\mathrm{Bc}}$ & $7.91 \pm 0.98^{\mathrm{Aab}}$ \\
\hline Karakoç & 5 & $16.56 \pm 1.03^{\mathrm{A}}$ & $13.83 \pm 0.58^{\mathrm{Ba}}$ & $13.66 \pm 0.53^{\mathrm{Bab}}$ & $6.67 \pm 1.01^{\mathrm{b}}$ & $8.58 \pm 0.73^{\mathrm{a}}$ & $9.09 \pm 0.07^{a}$ \\
\hline Ortanca & 3 & $17.35 \pm 0.55^{\mathrm{A}}$ & $10.70 \pm 1.54^{\mathrm{Bab}}$ & $10.37 \pm 2.05^{\mathrm{Bbc}}$ & $7.12 \pm 0.15^{\mathrm{ab}}$ & $8.05 \pm 0.51^{\mathrm{ab}}$ & $7.49 \pm 2.03^{\mathrm{ab}}$ \\
\hline Yalınağaç & 2 & $14.12 \pm 0.90^{\mathrm{A}}$ & $8.53 \pm 0.04^{\mathrm{Bb}}$ & $9.03 \pm 0.16^{\mathrm{Bc}}$ & $8.35 \pm 0.0002^{\mathrm{ab}}$ & $7.11 \pm 0.54^{\mathrm{ab}}$ & $4.71 \pm 1.77^{\mathrm{b}}$ \\
\hline Yukarıüneyce & 3 & $16.82 \pm 1.73$ & $13.95 \pm 1.08^{\mathrm{a}}$ & $14.03 \pm 1.13^{\mathrm{a}}$ & $7.12 \pm 0.53^{a b}$ & $7.69 \pm 0.25^{\mathrm{ab}}$ & $7.85 \pm 1.06^{\mathrm{ab}}$ \\
\hline \multirow[t]{2}{*}{ Genel ortalama } & 30 & $15.30 \pm 0.40^{1}$ & $12.67 \pm 0.40^{2}$ & $11.82 \pm 0.40^{2}$ & $7.82 \pm 0.23$ & $7.12 \pm 0.24$ & $7.91 \pm 0.42$ \\
\hline & & $\% \mathrm{HK}$ & & & & $\%$ ADL & \\
\hline Ağzıkara & 5 & $9.42 \pm 0.34^{\mathrm{B}}$ & $9.57 \pm 0.39^{\mathrm{Bab}}$ & $11.21 \pm 0.21^{\mathrm{Abc}}$ & $9.12 \pm 0.72^{\mathrm{bc}}$ & $8.08 \pm 1.09^{\mathrm{b}}$ & $10.87 \pm 1.58^{b}$ \\
\hline Erçek & 3 & $10.11 \pm 1.00$ & $10.96 \pm 1.01^{\mathrm{a}}$ & $10.60 \pm 0.60^{\mathrm{bc}}$ & $7.99 \pm 0.03^{\mathrm{Bc}}$ & $10.38 \pm 0.61^{\mathrm{ABb}}$ & $12.28 \pm 0.42^{\mathrm{Aab}}$ \\
\hline Gövelek & 4 & $10.13 \pm 0.40$ & $10.04 \pm 0.25^{\mathrm{ab}}$ & $10.38 \pm 0.37^{\mathrm{bc}}$ & $9.73 \pm 0.68^{\mathrm{bc}}$ & $10.38 \pm 0.61^{b}$ & $10.80 \pm 0.42^{\mathrm{b}}$ \\
\hline Karagündüz & 5 & $8.45 \pm 0.52$ & $8.96 \pm 0.30^{\mathrm{b}}$ & $9.88 \pm 0.50^{c}$ & $10.39 \pm 0.44^{\mathrm{bc}}$ & $9.75 \pm 1.31^{\mathrm{b}}$ & $12.08 \pm 0.47^{\mathrm{ab}}$ \\
\hline Karakoç & 5 & $10.04 \pm 0.33$ & $9.99 \pm 0.38^{\mathrm{ab}}$ & $10.66 \pm 036^{\mathrm{bc}}$ & $11.38 \pm 0.94^{\mathrm{bc}}$ & $11.11 \pm 0.61^{\mathrm{ab}}$ & $11.39 \pm 0.43^{b}$ \\
\hline Ortanca & 3 & $9.81 \pm 0.08^{\mathrm{B}}$ & $9.30 \pm 0.13^{\mathrm{Bab}}$ & $11.65 \pm 0.77^{\mathrm{Aab}}$ & $11.06 \pm 0.94^{\mathrm{ab}}$ & $10.66 \pm 2.02^{\mathrm{b}}$ & $12.33 \pm 1.30^{\mathrm{ab}}$ \\
\hline Yalınağaç & 2 & $10.15 \pm 0.07$ & $10.65 \pm 1.50^{\mathrm{ab}}$ & $12.96 \pm 0.52^{\mathrm{a}}$ & $13.11 \pm 0.36^{\mathrm{a}}$ & $14.61 \pm 0.74^{\mathrm{a}}$ & $15.32 \pm 0.67^{a}$ \\
\hline Yukarıüneyce & 3 & $9.77 \pm 0.52^{\mathrm{B}}$ & $10.87 \pm 0.30^{\mathrm{ABa}}$ & $11.54 \pm 0.27^{\mathrm{Aab}}$ & $9.12 \pm 1.29^{\mathrm{bc}}$ & $8.17 \pm 0.87^{\mathrm{b}}$ & $9.63 \pm 0.86^{\mathrm{b}}$ \\
\hline \multirow[t]{2}{*}{ Genel ortalama } & 30 & $9.65 \pm 0.19^{2}$ & $9.92 \pm 0.19^{2}$ & $10.87 \pm 0.20^{1}$ & $9.89 \pm 0.30^{2}$ & $10.10 \pm 0.46^{2}$ & $11.61 \pm 0.41^{1}$ \\
\hline & & $\%$ NDF & & & & $\%$ ADF & \\
\hline Ăğzıkara & 5 & $54.83 \pm 1.75^{c}$ & $54.94 \pm 1.30^{\mathrm{cd}}$ & $57.25 \pm 0.55$ & $37.93 \pm 1.53^{\mathrm{ABab}}$ & $38.79 \pm 1.18^{\mathrm{Ab}}$ & $34.65 \pm 0.80^{\mathrm{Bc}}$ \\
\hline Erçek & 3 & $57.84 \pm 2.54^{\mathrm{c}}$ & $63.66 \pm 3.20^{\mathrm{a}}$ & $56.82 \pm 1.66$ & $39.03 \pm 0.47^{\mathrm{ab}}$ & $38.62 \pm 0.16^{\mathrm{b}}$ & $35.59 \pm 2.65^{\mathrm{bc}}$ \\
\hline Gövelek & 4 & $58.74 \pm 0.68^{\mathrm{bc}}$ & $61.78 \pm 1.57^{\mathrm{ab}}$ & $59.73 \pm 2.07$ & $43.95 \pm 5.08^{\mathrm{ab}}$ & $43.07 \pm 3.14^{\mathrm{ab}}$ & $37.85 \pm 2.79^{\mathrm{bc}}$ \\
\hline Karagündüz & 5 & $62.35 \pm 1.00^{\mathrm{bc}}$ & $57.39 \pm 1.77^{\mathrm{abcd}}$ & $63.21 \pm 5.75$ & $38.63 \pm 1.35^{a b}$ & $42.16 \pm 2.22^{\mathrm{ab}}$ & $40.16 \pm 3.01^{\mathrm{abc}}$ \\
\hline Karakoç & 5 & $71.15 \pm 3.22^{\text {Аа }}$ & $52.58 \pm 0.54^{\mathrm{Bd}}$ & $57.20 \pm 2.57^{\mathrm{B}}$ & $37.59 \pm 0.38^{\mathrm{Cab}}$ & $42.39 \pm 0.23^{\mathrm{Aab}}$ & $39.72 \pm 1.05^{\mathrm{Babc}}$ \\
\hline Ortanca & 3 & $56.90 \pm 2.27^{c}$ & $58.13 \pm 3.57^{\mathrm{abcd}}$ & $63.82 \pm 2.66$ & $35.47 \pm 1.85^{b}$ & $41.39 \pm 2.38^{b}$ & $43.37 \pm 2.76^{\mathrm{ab}}$ \\
\hline Yalınağaç & 2 & $65.68 \pm 1.06^{\mathrm{ab}}$ & $61.52 \pm 2.59^{\mathrm{abc}}$ & $64.53 \pm 3.35$ & $46.24 \pm 0.62^{a}$ & $48.12 \pm 2.05^{a}$ & $47.73 \pm 0.41^{\mathrm{a}}$ \\
\hline Yukarıgüneyce & 3 & $55.10 \pm 3.02^{\mathrm{c}}$ & $55.72 \pm 2.39^{\mathrm{bcd}}$ & $60.05 \pm 5.77$ & $38.76 \pm 3.98^{\mathrm{ab}}$ & $41.21 \pm 0.56^{\mathrm{b}}$ & $43.46 \pm 3.26^{\mathrm{ab}}$ \\
\hline Genel ortalama & 30 & $60.58 \pm 1.27$ & $57.57 \pm 0.89$ & $59.94 \pm 1.27$ & $39.29 \pm 0.94$ & $41.63 \pm 0.72$ & $39.56 \pm 9.99$ \\
\hline
\end{tabular}

A;B,C; Her bir kriter için aynı satırda dönemler arasında farklı harfleri taşıyan değerler önemlidir $(\mathrm{P}<0.05)$; $a$, b, c: Her bir kriter için aynı sütün köyler arasında farklı harfleri taşıyan değerler arasındaki farklılık önemlidir $(\mathrm{P}<0.05)$; 1,2,3: Her bir kriter için aynı satırda dönemler arasında farklı rakamları taşıyan değerler önemlidir ( $\mathrm{P}<0.05)$. 
Yukarıüneyce köyünde tarlada kurutulan yonca HP oranı \% 13.95 ile Yalınağaç köyüne göre yüksek $(\mathrm{P}<0.05)$ iken, diğer köyler ile benzer olduğu görülmüsstür. Depodan alınan örneklerde de Yukarıüneyce köyü yonca HP oranı Yalınağaç ve Ortanca köylerine göre yüksek bulunmuştur $(\mathrm{P}<0.05)$. Hasat sonrası kapalı ortamda kurutulan yoncanın HK oranları köyler arasında farklılık bulunmazken, tarlada kurutulmuş ve depodan alınan örneklerde farklılık bulunmuştur $(\mathrm{P}<0.05)$. Erçek köyünde tarlada kurutulan yonca HK oranı \% 10.96 ile Karagündüz köyü yonca otu HK (\% 8.96) içeriğine göre yüksek iken $(\mathrm{P}<0.05)$, diğer köyler ile benzer bulunmuştur. Depodan alınan örneklerinde ise Karagündüz köyü yonca HK (\% 9.88) oranı Ortanca, Yalınağaç ve Yukarıgüneyce köylerine göre düşük bulunmuştur $(\mathrm{P}<0.05)$. Yalınağaç köyünde hasat sonrası kapalı ortamda kurutulan yonca ADL miktarı \% 13.11 ile Ortanca köyü hariç diğer köylere göre yüksek $(\mathrm{P}<0.05)$ iken bu durum tarlada kurutma sonrası ve depodan alınan örneklere de yansımıştır. Depodan alınan örneklerinde Yalınağaç köyü yonca ADL (\% 15.32) oranı Ağzıkara, Gövelek, Karakoç ve Yukarıüneyce köylerine göre yüksek bulunmuştur $(\mathrm{P}<0.05)$. Karakoç köyünde hasat sonrası kapalı ortamda kurutulan yonca HY (\% 6.67) oran1 ile Ağzıkara köyüne göre düşük $(\mathrm{P}<0.05)$, tarlada kurutulmuş yoncada (\% 8.58) ile Erçek ve Karagündüz köylerine göre ve depolardan alınan yonca örneklerinde ise (\% 9.09) ile Yalınağaç köyüne göre yüksek bulunmuştur $(\mathrm{P}<0.05)$.

Ortanca köyünde hasat sonrası kapalı ortamda kurutulan yonca NDF (\% 56.90) oranı Karakoç ve Yalınağaç köylerine düşük $(\mathrm{P}<0.05)$, tarlada kurutulan Karakoç köyü yonca NDF (\% 52.58) oranı ise Erçek, Gövelek ve Yalınağaç köylerine göre düşük bulunmuştur $(\mathrm{P}<0.05)$. Depolardan alınan yonca örneklerin de NDF oranları köyler arasında benzer bulunmuştur. Yalınağaç köyünde hasat sonrası kapalı ortamda kurutulan yonca ADF (\% 46.24) oranı Ortanca köyüne göre tarlada kurutulan yonca ADF (\% 48.12) oranı Erçek, Ortanca ve Yukarıüneyce köylerine göre ve depolardan alınan (\% 47.73) örneklerde ise Ağzıkara, Erçek ve Gövelek köylerine göre yüksek bulunmuştur $(\mathrm{P}<0.05)$.

Söz konusu işletmelerden Ortanca, Karakoç, Erçek, Ağzıkara, Gövelek, Yukarıüneyce ve Yalınağaç köylerinde yonca hasadı çiçeklenme başlangıcı, çiçeklenme ortasında; Karagündüz köyünde ise çiçeklenme sonu tohum bağlama başlangıcında yapılmıştır. Hasat sonrası yonca otunun taşınması ve saklanmasında uygulanan işlemler genelde benzerdir. Tüm köylerde biçilen yonca otları tarlalarda namlu veya bağ şeklinde kurutulup 4 ile 25 gün gibi değişik sürelerde bekletilen yonca otları römorklar üzerinde taşınıp ya bağ şeklinde brandalar altında yığınlar halinde veya patozlanarak kapalı ortamda kes halinde saklanmaktadır. İşletmelerin 16's1 yonca kuru otlarını patozlayarak kes halinde kapalı ortamlarda depolarken, 14 işletme ise ahır yakınlarında yağışlar artıncaya kadar yaklaşık 4 ay süreyle üstü açık yığınlar halinde beklettikleri otlarını çadırla örtmektedirler. Hasat edilen yemlerin patozlanarak kes haline getirilmesi besin madde kaybına neden olacağı (Deniz ve ark., 2000) gibi yemlerin tarlada kurutma süresi ve şekli ile tarladan depoya taşınmasındaki yaprak kayıpları da etkili olmaktadır. Yaprak kayıpları özellikle yemlerde protein ve mineral miktarlarının azalmasına yapısal karbonhidratlarının ise artmasına neden olmaktadır. Yemlerin besin madde değerleri hasat zamanına bağlı olarak değiştiği, hasat döneminin ilerlemesi ile yemlerin KM ve yapısal karbonhidrat miktarı artarken HP miktarının düştügü bilinmektedir (Kim ve ark., 2004; Güngör ve ark., 2008; Canbolat ve Karaman, 2009; Ünalp, 2014; Dumlu Gül ve ark., 2015; Adıyaman ve Ayhan, 2016).

Hasattan sonra yemlerin güneş ve yağmura maruz kalması da besin madde miktarının azalmasına neden olduğu ve özellikle proteince zengin yaprak kısımlarının azalması ile yapısal karbonhidratların arttı̆̆ 1 bildirilmektedir (Oktay ve ark., 1984).

Yoncanın \% 10 çiçeklenmede yaprak miktarının optimum ve lignin miktarının minimum olduğu (Özyiğit ve Bilgen, 2006) genç hücre çeperlerinde düşük olan HY miktarı yaprak kaybı ile yükseldiği (Kamalak ve ark., 2005) bildirilmektedir. Kapalı ortamda kurutulmuş yoncada \% 140.86 olan toplam karoten düzeyi tarlada kurutma sonrası ve depolardan alınan örneklerde sirasıyla \% 109.63 ve 118.09 ' a düşmüştür $(\mathrm{P}<0.05)$. Kapalı ortamda kurutulan yonca Ca düzeyi $\% 1.66$ 'dan depolardan alınan örneklerde \%1.38' e benzer şekilde $\mathrm{K}$ ve Na içeriği de kapalı ortamda kurutulan yoncada sirasiyla \% 2.32 ve $\% 0.07$ 'den tarlada kurutma sonrasinda $\% 2.04$ ve $\% 0.04$ 'e düşmüştür $(\mathrm{P}<0.05$; Çizelge 3.3). 
Çizelge 3.3. Yonca kuru otlarının toplam karoten, Ca, K, Na ve Mg değerlerine ait en küçük kareler ortalaması ve standart hata sonuçları

\begin{tabular}{|c|c|c|c|c|c|}
\hline & $\mathrm{N}$ & & Kapalı ortamda kurutma & Tarlada kurutma & Depolama sonras1 \\
\hline Ağgıkara & 5 & \multirow{9}{*}{ 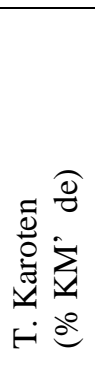 } & $131.24 \pm 9.91^{\mathrm{bc}}$ & $121.59 \pm 17.04^{\mathrm{ab}}$ & $134.68 \pm 24.54^{\mathrm{ab}}$ \\
\hline Erçek & 3 & & $158.72 \pm 2.51^{\mathrm{ab}}$ & $92.01 \pm 17.73^{\mathrm{bc}}$ & $104.98 \pm 28.59^{\mathrm{ab}}$ \\
\hline Gövelek & 4 & & $140.32 \pm 7.18^{\mathrm{abc}}$ & $117.81 \pm 24.34^{\mathrm{ab}}$ & $139.22 \pm 19.96^{\mathrm{ab}}$ \\
\hline Karagündüz & 5 & & $111.43 \pm 6.64^{\mathrm{c}}$ & $77.37 \pm 9.62^{\mathrm{bc}}$ & $75.38 \pm 15.74^{\mathrm{ab}}$ \\
\hline Karakoç & 5 & & $171.69 \pm 16.85^{\mathrm{a}}$ & $164.07 \pm 9.27^{\mathrm{a}}$ & $150.08 \pm 14.84^{\mathrm{a}}$ \\
\hline Ortanca & 3 & & $143.94 \pm 7.49^{\mathrm{abc}}$ & $118.39 \pm 17.32^{\mathrm{ab}}$ & $121.95 \pm 38.32^{\mathrm{ab}}$ \\
\hline Yalınağaç & 2 & & $131.68 \pm 1.96^{\mathrm{Abc}}$ & $53.40 \pm 10.17^{\mathrm{Bc}}$ & $52.38 \pm 18.53^{\mathrm{Bb}}$ \\
\hline Yukarıgüneyce & 3 & & $140.51 \pm 14.60^{\mathrm{abc}}$ & $88.17 \pm 17.83^{\mathrm{bc}}$ & $133.24 \pm 43.00^{\mathrm{ab}}$ \\
\hline Genel ortalama & & & $140.86 \pm 4.97^{1}$ & $109.63 \pm 7.74^{2}$ & $118.09 \pm 9.53^{2}$ \\
\hline A ğzıkara & 5 & \multirow{9}{*}{ 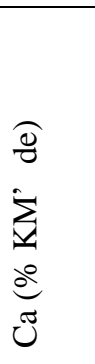 } & $1.84 \pm 0.07^{\mathrm{A}}$ & $1.29 \pm 0.14^{\mathrm{Bab}}$ & $1.40 \pm 0.16^{\mathrm{Bab}}$ \\
\hline Erçek & 3 & & $1.94 \pm 0.27$ & $1.66 \pm 0.44^{\mathrm{a}}$ & $1.53 \pm 0.22^{\mathrm{ab}}$ \\
\hline Gövelek & 4 & & $1.85 \pm 0.34$ & $1.35 \pm 0.05^{\mathrm{ab}}$ & $1.39 \pm 0.17^{\mathrm{ab}}$ \\
\hline Karagündüz & 5 & & $1.38 \pm 0.13^{\mathrm{A}}$ & $1.65 \pm 0.12^{\mathrm{Aa}}$ & $0.98 \pm 0.10^{\mathrm{Bb}}$ \\
\hline Karakoç & 5 & & $1.62 \pm 0.11$ & $1.64 \pm 0.1^{\mathrm{a}}$ & $1.61 \pm 0.19^{\mathrm{ab}}$ \\
\hline Ortanca & 3 & & $1.51 \pm 0.15$ & $1.28 \pm 0.02^{\mathrm{ab}}$ & $1.00 \pm 0.35^{\mathrm{b}}$ \\
\hline Yalınağaç & 2 & & $1.60 \pm 0.12^{\mathrm{A}}$ & $0.97 \pm 0.14^{\mathrm{Bb}}$ & $1.40 \pm 0.09^{\mathrm{ABab}}$ \\
\hline Yukarıgüneyce & 3 & & $1.54 \pm 0.06$ & $1.52 \pm 0.10^{\mathrm{ab}}$ & $1.87 \pm 0.13^{\mathrm{a}}$ \\
\hline Genel ortalama & & & $1.66 \pm 0.07^{1}$ & $1.45 \pm 0.06^{2}$ & $1.38 \pm 0.07^{2}$ \\
\hline Ağzıkara & 5 & \multirow{9}{*}{$\begin{array}{l}\stackrel{8}{8} \\
\sum_{z} \\
\underbrace{0}\end{array}$} & $2.60 \pm 0.33$ & $1.83 \pm 0.50^{\mathrm{b}}$ & $2.22 \pm 0.26^{\mathrm{ab}}$ \\
\hline Erçek & 3 & & $1.93 \pm 0.20$ & $1.75 \pm 0.05^{b}$ & $1.97 \pm 0.29^{\mathrm{ab}}$ \\
\hline Gövelek & 4 & & $2.74 \pm 0.21$ & $2.65 \pm 0.20^{\mathrm{a}}$ & $2.71 \pm 0.32^{\mathrm{a}}$ \\
\hline Karagündüz & 5 & & $2.01 \pm 0.20$ & $1.97 \pm 0.16^{\mathrm{ab}}$ & $1.85 \pm 0.19^{b}$ \\
\hline Karakoç & 5 & & $2.21 \pm 0.13$ & $2.04 \pm 0.16^{\mathrm{ab}}$ & $2.27 \pm 0.10^{\mathrm{ab}}$ \\
\hline Ortanca & 3 & & $2.22 \pm 0.10$ & $1.76 \pm 0.53^{\mathrm{b}}$ & $1.76 \pm 0.20^{\mathrm{b}}$ \\
\hline Yalınağaç & 2 & & $2.56 \pm 0.41$ & $2.06 \pm 0.26^{\mathrm{ab}}$ & $1.95 \pm 0.55^{\mathrm{ab}}$ \\
\hline Yukarıgüneyce & 3 & & $2.32 \pm 0.11$ & $2.18 \pm 0.30^{\mathrm{ab}}$ & $1.65 \pm 0.20^{\mathrm{b}}$ \\
\hline Genel ortalama & & & $2.32 \pm 0.09^{1}$ & $2.04 \pm 0.08^{2}$ & $2.09 \pm 0.09^{12}$ \\
\hline Ağzıkara & 5 & \multirow{9}{*}{ 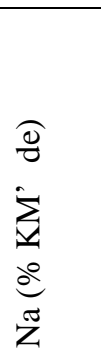 } & $0.11 \pm 0.03^{\mathrm{Aa}}$ & $0.09 \pm 0.01^{\mathrm{ABabc}}$ & $0.05 \pm 0.006^{\mathrm{B}}$ \\
\hline Erçek & 3 & & $0.10 \pm 0.03^{\mathrm{a}}$ & $0.13 \pm 0.07^{a}$ & $0.05 \pm 0.002$ \\
\hline Gövelek & 4 & & $0.11 \pm 0.007^{\mathrm{Aa}}$ & $0.11 \pm 0.02^{\mathrm{Aab}}$ & $0.05 \pm 0.005^{\mathrm{B}}$ \\
\hline Karagündüz & 5 & & $0.06 \pm 0.017^{\mathrm{ab}}$ & $0.06 \pm 0.01^{\mathrm{abc}}$ & $0.05 \pm 0.01$ \\
\hline Karakoç & 5 & & $0.03 \pm 0.004^{\mathrm{b}}$ & $0.03 \pm 0.002^{\mathrm{bc}}$ & $0.03 \pm 0.005$ \\
\hline Ortanca & 3 & & $0.03 \pm 0.008^{\mathrm{b}}$ & $0.02 \pm 0.004^{\mathrm{c}}$ & $0.03 \pm 0.004$ \\
\hline Yalınağaç & 2 & & $0.02 \pm 0.005^{\mathrm{b}}$ & $0.03 \pm 0.002^{\mathrm{bc}}$ & $0.03 \pm 0.008$ \\
\hline Yukarıgüneyce & 3 & & $0.02 \pm 0.002^{\mathrm{b}}$ & $0.03 \pm 0.006^{\mathrm{bc}}$ & $0.03 \pm 0.003$ \\
\hline Genel ortalama & & & $0.07 \pm 0.0^{\mathrm{a} 1}$ & $0.07 \pm 0.01^{1}$ & $0.04 \pm 0.003^{2}$ \\
\hline Ăgzzlkara & 5 & \multirow{9}{*}{ 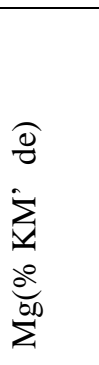 } & $0.28 \pm 0.03$ & $0.22 \pm 0.44^{\mathrm{ab}}$ & $0.24 \pm 0.03$ \\
\hline Erçek & 3 & & $0.22 \pm 0.06$ & $0.27 \pm 0.07^{\mathrm{a}}$ & $0.24 \pm 0.04$ \\
\hline Gövelek & 4 & & $0.26 \pm 0.03^{\mathrm{A}}$ & $0.22 \pm 0.02$ ABab & $0.15 \pm 0.03^{\mathrm{B}}$ \\
\hline Karagündüz & 5 & & $0.23 \pm 0.03$ & $0.22 \pm 0.04^{\mathrm{ab}}$ & $0.18 \pm 0.22$ \\
\hline Karakoç & 5 & & $0.25 \pm 0.02$ & $0.17 \pm 0.02^{\mathrm{ab}}$ & $0.19 \pm 0.03$ \\
\hline Ortanca & 3 & & $0.21 \pm 0.02^{\mathrm{A}}$ & $0.10 \pm 0.007^{\mathrm{Bb}}$ & $0.20 \pm 0.004^{\mathrm{A}}$ \\
\hline Yalınağaç & 2 & & $0.20 \pm 0.02$ & $0.23 \pm 0.07^{\mathrm{ab}}$ & $0.22 \pm 0.05$ \\
\hline Yukarıgüneyce & 3 & & $0.18 \pm 0.02$ & $0.25 \pm 0.03^{a}$ & $0.21 \pm 0.02$ \\
\hline Genel ortalama & & & $0.23 \pm 0.01$ & $0.21 \pm 0.015$ & $0.20 \pm 0.01$ \\
\hline
\end{tabular}

A,B, C: Her bir kriter için aynı satırda dönemler arasında farklı harfleri taşıyan değerler önemlidir $(\mathrm{P}<0.05)$; $a, b$, c: Her bir kriter için aynı sütün köyler arasında farklı harfleri taşıyan değerler arasındaki farklılık önemlidir $(\mathrm{P}<0.05) ; 1,2$ : Her bir kriter için aynı satırda dönemler arasında farklı harfleri taşıyan değerler önemlidir $(\mathrm{P}<0.05)$.

Bütün köylerin kapalı ortamlarda kurutulan yonca örneklerinde toplam karoten düzeyi yüksek olup tarlada kurutulan ve depolardan alınan örneklerde düşmüştür $(\mathrm{P}<0.05)$. Toplam karoten bakımından köyler arası farklılıkların olduğu, Karakoç köyünde kapalı ortamda kurutulan yonca örneklerinin toplam karoten değerleri Karagündüz ve Yalınağaç köyüne göre; tarlada kurutma sonrasında alınan örneklerde Karagündüz, Erçek, Yalınağaç ve Yukarıgüneyce köylerine göre depolardan alınan örneklerde ise yalnızca Yalınağaç köyüne göre yüksek bulunmuştur $(\mathrm{P}<0.05)$. 
Ağzıkara, Karagündüz ve Yalınağaç köylerinde kapalı ortamlarda kurutulan yonca örneklerinde Ca düzeyleri yüksek iken depolardan alınan örneklerinde sırasıyla \% 1.40, 0.98 ve 1.40'a düşmüştür $(\mathrm{P}<0.05)$. Kapalı ortamlarda kurutulan yonca örneklerinin $\mathrm{Ca}$ düzeyleri bakımından köyler arasında farklılığın görülmediği, tarlada kurutma sonrasında Karakoç köyü ile Yalınağaç köyü arasında ve depodan alınan örneklerde ise Ortanca köyü ile Yukarıgüneyce köyü arasında bir farklılık görülmüştür $(\mathrm{P}<0.05)$. Kapalı ortamlarda kurutulan, tarlada kurutulan ve depolardan alınan yonca örneklerinin $\mathrm{K}$ düzeyleri bakımından farklılıkların olmadığı gibi kapalı ortamda kurtulan yonca örneklerinin $\mathrm{K}$ düzeyleri bakımından köyler arasında farlılıklar bulunmamıştır. Tarlada kurutma sonrası kurutulan örneklerde Gövelek ve Ortanca köyü arasında depolardan alınan örneklerde ise Gövelek köyü ile Karagündüz; Ortanca ve Yukarıüneyce köyleri arasında farklılık gözlenmiştir $(\mathrm{P}<0.05)$.

Ağzıkara ve Gövelek köylerinde kapalı ortamında kurutulan yoncanın Na içerikleri \% 0.11 iken depodan alınan örneklerde \% 0.05’e düşmüştür $(\mathrm{P}<0.05)$. Ağzıkara, Erçek ve Gövelek köylerinde kapalı ortamlarda ve tarlada kurutulan yoncanın $\mathrm{Na}$ içerikleri diğer köylere göre yüksek bulunmuştur $(\mathrm{P}<0.05)$. Gövelek ve Ortanca köylerinde kapalı ortamında kurutulan yoncanın $\mathrm{Mg}$ içerikleri hasattan sonra geçen süreye bağlı olarak değişmekle birlikte $(\mathrm{P}<0.05)$, tarlada kurutulan yoncanın $\mathrm{Mg}$ içeriği Erçek ve Ortanca köyleri arasında farklılık görülürken $(\mathrm{P}<0.05)$ diğer köyler arasında yonca $\mathrm{Mg}$ içerikleri bakımından farklılık görülmemiştir (Çizelge 3.3). Toplam karoten içerikleri ile Ca ve $\mathrm{Na}$ içerikleri değerlendirildiğinde güneş altında ve yağmurlu havalarda kurutmadan dolayı kayıplar olmuştur.

Yonca kuru otunun kuru maddesinde toplam karoten düzeyi $125 \mathrm{mg} / \mathrm{kg}$ olduğu (CruzMonterrossa ve ark., 2011), taze yoncada yüksek olan toplam karoten içeriğinin mikrodalga firınında, oda sıcaklığında, 96 saat güneş ve yağmurla birlikte güneş gibi farklı yöntemlerle kurutulduğunda hızlı bir şekilde düştüğü bildirilmektedir (Park ve ark., 1983). Bazı yonca çeşitlerinin biçim sayısına ve biçim yılına bağlı olarak mineral madde ve özellikle Ca içeriklerinin değiştiği (Turan, 2010; Engin ve Mut, 2018), Ca bakımından kaybın en çok uzun süre yağmur altında kurutulan yoncalarda olduğu (Oktay ve ark., 1984) bildirilmektedir. Yonca besin maddelerinde görülen değişimin ve farklılıkların hasat sonrası tarlada bekletilme süresinin etkili olabileceği gibi, yemlerin depoya taşınmasındaki kayıpların yanında iklim koşullarının da etkili olduğu bildirilmektedir (Oktay ve ark., 1984). Hatta otların içerisine tarladan depolamaya kadar ki taşıma sürecinde taş, toprak, kum ve çakıl gibi inorganik maddelerin bulaşmış olabilme ihtimali de göz ardı edilmemelidir.

Hasat sonrası kapalı ortamda kurutulmuş, tarlada kurutulmuş ve depolardan alınan yonca otu örneklerinde aflatoksin B1, B2, G1 ve G2 çeşitlerine rastlanılmamıştır. Van ili yetiştirici şartlarında elde edilen ve depolanan kaba yem örneklerinin \% nem içerikleri ile yıllık yağış, sıcaklık ve nispi nem ortalamaları bakımından yemlerde aflatoksin oluşumu ile toksijenik küf gelişimi bakımında olumsuz etkilenmediği, (Demirel ve Yıldırım, 2001) bildirilmektedir. 44 yonca kuru ot örneklerinde yapılan bir çalışmada, aflatoksin B1 konsantrasyonlarının minimum ( $0.00 \mu \mathrm{g} / \mathrm{kg}$ ) ve maksimum ( $66.57 \mu \mathrm{g} / \mathrm{kg}$ ) düzeylerin yasal sınırlar üzerinde olduğu (Hashemi, 2016), 76 kaba yem örneğinin ortalama aflatoksin B1 düzeyinin $1.02 \mu \mathrm{g} / \mathrm{kg}$, maksimum düzeyinin ise $11.37 \mu \mathrm{g} / \mathrm{kg}$ olduğu bildirilmektedir (Bilal ve ark., 2014).

Sonuç olarak, yonca kuru otunun kalitesini etkileyen faktörlerin başında hasat zamanı gelmektedir. Karagündüz ve Ağzıkara köylerinde yonca hasatının tam çiçeklenme hatta aynı köyün bazı işletmelerinde tohum bağlama döneminde yapılmasından dolayı hasat anında yonca KM içeriği \% 37.50 -\% 40.90' lara ulaşmıştır. Hasattan sonra kapalı ortamda kurutulan yoncada yüksek olan HP, toplam karoten, $\mathrm{Ca}$ ve Na içerikleri ile düşük olan ADL içeriklerinin hasattan sonra tarlada kurutma ortamı ve süresi ile yonca otlarının taşınması, patozlanması ve depolanması süresince yağan kar, yağış ve çiğ gibi olaylara bağlı olarak HP, toplam karoten, Ca ve Na içeriklerinin azaldığı ve ADL içeriğinin ise arttığı görülmüştür. Yoncanın \% 10-15 çiçeklenme döneminde hasat edilip tarlada kuruması için uzun süre bekletilmeden en kısa sürede işletmelere taşınıp kapalı yağış almayacak şekilde sundurmalar altında patozlanmadan depolanması yaprak kaybını minimize edeceğinden besin madde kaybı önlenmiş olacaktır. 


\section{Teşekkür}

TYL-2019-8569 proje numarası ile bu çalışmayı destekleyen Van Yüzüncü Yı1 Üniversitesi Bilimsel Araştırma Projeleri Başkanlığı'na ve Doç. Dr. Sibel ERDOĞAN'a teşekkür ederiz.

\section{Kaynakça}

Adiyaman, E., \& Ayhan, V. (2016). Investigation of feed value of alfalfa (Medicago sativa L.) harvested of diffrent maturity stages. Legume Research, 39(2), 237-247.

Anonim. (2018). Ípekyolu tarım ve orman ilçe müdürlüğü tarımsal verileri.

Anonim. (2019). Van Meteoroloji Bölge Müdürlüğü Verileri.

AOAC. (1990). Association of Official Analtical Chemists. Officials Methods of Analysis, 15th print. Washington, DC. 1, 69-79.

AOAC. (2005). AOAC Official Method 2003.02. Aflatoxin B1 in Cattle Feed. Officials Methods of Analysis AOAC International, Gaitshersburg, MD. F

Arıkan, L., \& Çevik, D. (2012). Aflatoksinler ve süt teknolojisindeki önemi. III. Süt ve Süt Hayvancıllğı Öğrenci Kongresi. 21 Mayıs 2012, Aksaray. 71-76.

Basmacıoğlu, H., \& Ergül, M. (2003). Yemlerde bulunan toksinler ve kontrol yolları. Hayvansal Üretim, 44(1), 9-17.

Bastaban, S., Erkmen, Y., \& Nalbant, M. (1983). Köy koşullarında yoncanın depolanması ve depolama süresince oluşan ham protein kayıpları üzerinde bir araştırma. Atatürk Üniversitesi Ziraat Fakültesi Dergisi, 15(3-4), 47-54.

Bilal, T., Aksakal, Hilkat, D., Sünnetci, S., Keser, O., \& Eseceli, H. (2014). Detection of aflatoxin, zearalenone and deoxynivalenol in some feed and feedstuffs in Turkey. Pakistan Veterinary Journal, 34(4), 459-463.

Canbolat, Ö., \& Karaman, Ş. (2009). Bazı baklagil kaba yemlerinin in vitro gaz üretimi, organik madde sindirimi, nispi yem değeri ve metabolik enerji içeriklerinin karşılaştırılması. Ankara Üniversitesi Tarım Bilimleri Dergisi, 15(2),188-195.

Cruz-Monterrosa, R. G., Ramírez-Bribiesca, J. E., Guerrero Legarreta, M. J., \& Hernández-Mendo, O., (2011). Carotenoids digestion in African stargrass (Cynodon plectostachyus) determined with in situ techniques in cattle. Tropical and Subtropical Agroecosystems, 14, 1011-1017.

Demirel, M., \& Yıldırım, A. (2000). Van yöresinde yetiştirici şartlarında depolanan kaba yemlerde aflatoksin oluşumunun saptanması. Yüzüncü Yll Üniversitesi Ziraat Fakültesi Tarım Bilimleri Dergisi, 10(1), 77-83.

Deniz, S., Denek, N., Karslı, M. A., Yumak, H., \& Nursoy, H., (2000). Farklı batözlerle ögü̈menin kaba yemlerin besin madde içeriği ile yem tüketimi ve sindirilme derecesine etkisi. Yüzüncü Yll Üniversitesi Veteriner Fakültesi Dergisi, 11(2), 82-86.

Dumlu Gül, Z., Tan, M., Fayetörbay Kaynar, D., \& Kharazmi, K., (2015). Effects of some additives, harvest stage and wilting on quality characteristics of alfalfa silage. Atatürk Üniversitesi Ziraat Fakültesi Dergisi, 46 (2), 113-118.

Engin, B., Mut, H., (2018). Bazı yonca (Medicago sativa L.) çeşitlerinin nispi yem değerleri ile kimi mineral madde içeriklerinin biçim sıralarına göre değişimi. Tekirdağ Ziraat Fakültesi Dergisi, 15(2), 119-127.

Erkan, O., O., Orhan, F., Budak, H. Şengül, 1991. Aşağ1 Mardin-Ceylanpınar ovalarındaki tarım işletmelerinin ekonomik analizi ve ileriye dönük planlaması, Doğa Tr. Journal of Agriculture and Forestry, 15, 58-67.

Fan, W., Ge, G., Liu, Y., Liu, W., W. L., Jia, Y., (2018). Proteomics integrated with metabolomics: analysis of the internal causes of nutrient changes in alfalfa at different growth stages. BMC Plant Biology, 18(78), 1-15.

Güngör, T., Başalan, M., Aydoğan, İ., (2008). Kırıkkale yöresinde üretilen bazı kaba yemlerde besin madde miktarları ve metabolize olabilir enerji düzeylerinin belirlenmesi. Ankara Üniversitesi Veteriner Fakültesi Dergisi, 55, 111-115.

Hashemi, M., (2016). Aflatoxin B1 levels in feedstuffs from dairy cow farms in south of Iran. Food and Agricultural Immunology, 27(2),251-258. 
Kamalak, A., Canbolat, Ö., Şahin, M., Gürbüz, Y., Özköse, E., Özkan, C.O., (2005). The effect of polyethylene glycol (PEG 8000) supplementation on in vitro gas production kinetics of leaves from tannin containing trees. South African Journal of Animal Science, 35(4), 229-237.

Karabulut, A., \& Canbolat, Ö. (2005). Yem Değerlendirme ve Analiz Yöntemleri. Uludağ Üniversitesi Ziraat Fakültesi Yayınları No: 2.05.048.0424. 515s

Kim, J. D., Kwon, C. H., Kim, H. J., \& Kim, M. G., (2004). Effect of species and tedding frequency on the quality of annual legume hay in spring. J. Anim. Sci. and Technol., 46(3), 451-458.

Komarek, R.J., Komarek, A.R., \& Layton, B. (2004). Chapter 4. Evaluation of the rapid high temparature extraction of feeds, foods and oil seeds by the ANKOMXT20 fat analyzer to the determine crude fat content. Oil Extraction and Analysis. AOCS Press. 41-68.

Kutlu, H. R. (2008). Yem Değerlendirme ve Analiz Yöntemleri. Çukurova Üniversitesi Ziraat Fakültesi Zootekni Bölümü Adana.68.

Nascimento, J. M., Costa, C., Silveira, A. C., \& Mário Arrigoni, B. (2000). Haying method and storage length effects on chemical composition and mold. Rev. Bras. Zootechnia, 29(3), 669677.

Neres, M., Castagnara, D., Mesquita, E. E., \& Zambom, M. A. (2010). Production of alfalfa hay under different drying methods. Revista Brasileira de Zootecnia, 39(8), 1676-1683.

Oktay, E., Olgun, H., \& Ünal, S. (1984). Çeşitli koşullarda kurutulan yoncanın besin değerleri kaybı üzerinde bir araştırma. Lalahan Zootekni Araştırma Enst. Derg, 24(1-4), 3-14.

Özyiğit, Y., \& Bilgen, M. (2006). Bazı baklagiller yem bitkilerinde farklı biçim dönemlerinin bazı kalite faktörleri üzerine etkisi. Akdeniz Üniversitesi Ziraat Fakültesi Dergisi, 19(1), 29-43.

Park, Y. W., Anderson, M. J., Walters, J. L., \& Mahoney, A. W. (1983). Effects of processing methods and agronomic variables on carotene contents in forages and predicting carotene in alfalfa hay with near-infrared-reflectance spectroscopy. Journal of Dairy Science, 66, 235245.

SAS. (2014). SAS/STAT User' Guide: Statistics. Hangen and Enhanced, Version 9.4, SAS, Inst. Inc. Cary, N.C. USA.

Stancher, B., \& Zonta, F. (1982). High-performance liquid chromatographic determination of carotene and vitamin A and its geometric isomers in foods : Applications of cheese analysis. Journal of Chromatography A, 238, 217-225.

Stavarache, M., \& Samu1, C. (2015). The productivity and quality of alfalfa (Medicago sativa L.) in Romanian forest steppe. Not Bot Horti Agrobo, 43(1), 179-185.

Turan, N. (2010). Bazı yonca (Medicago Sativa L.) çeşitlerinin farklı ekim zamanlarında verim ve verim unsurlarının belirlenmesi üzerinde bir araştırma (doktora tezi- basılmamış). Yüzüncü Y11 Üniversitesi fen Bilimleri Enstitüsü, Van.

Ünalp, A.E. (2014). Farklı gelişme dönemleri ve biçim sıralarında yonca (Medicago Sativa L.) kuru otunun ham protein, selüloz ve bazı mikrobiyolojik özelliklerinin belirlenmesi (yüksek lisans tezi, basılmamış). Namık Kemal Üniversitesi Fen Bilimleri Enstitüsü, Tekirdağ.

Van Soest, P.J., Robertson, J.B., \& Lew1s. B.A. (1991). Methods for Dietary Fiber, Neutral Detergent Fiber, and Nonstarch polysaccharides in relation to animal nutrition. Journal of Dairy Science, 74(10), 3583-3597. 